\title{
Chapter 1 \\ Introduction to the Conceptualisation of Environmental Citizenship for Twenty-First-Century Education
}

\author{
Andreas Ch. Hadjichambis and Pedro Reis
}

\subsection{Introducing Environmental Citizenship}

The EU's growth strategy (Europe 2020) and the European vision for green, circular and low-carbon economy in line with the EU 2050 (EU-roadmap 2050) give particular attention to citizens' participation and engagement and therefore to Environmental Citizenship. Environmental Citizenship has been an influential concept in many different arenas such as economy, policy, philosophy, corporation management and marketing, which could also be better exploited and established in the field of education. Environmental Citizenship is recognized as an important aspect in addressing global environmental problems such as climate change (Stern 2011; Ockwell et al. 2009) whilst providing support to pro-environmental organisations and individuals, contributing also to public pressure for political action (signing petitions, writing to politicians and newspapers). Many varied definitions of Environmental Citizenship can be found within the literature. Some of them are quite similar, and important overlaps can be observed; however, others can be quite different with contradictions in their philosophy and approach. According to Dobson (2010), Environmental Citizenship refers to pro-environmental behaviour, in public and in private, driven by a belief in fairness of the distribution of environmental goods, in participation and in the co-creation of sustainability policy. It is about the active participation of citizens in moving towards sustainability.

\footnotetext{
A. Ch. Hadjichambis ( $\bowtie)$

Cyprus Centre for Environmental Research and Education, CYCERE, Lemesos, Cyprus

Cyprus Ministry of Education and Culture, Nicosia, Cyprus

e-mail: a.chadjihambi@cytanet.com.cy

P. Reis

Instituto de Educação - Universidade de Lisboa, Alameda da Universidade, Lisboa, Portugal e-mail: preis@ie.ulisboa.pt
} 
Education and especially environmental discourses in science education have a lot to contribute in adopting and promoting Environmental Citizenship. However, the conceptualisation of Environmental Citizenship in educational context remains an imperative need. The under-explored (until now) potential for pro-environmental behaviour change through Environmental Citizenship should be further emphasised (Dobson 2010) and can contribute greatly to a more sustainable world.

\subsubsection{The Need for Environmental Citizenship}

We are currently experiencing an unprecedented environmental crisis. A series of existing environmental problems (both global and local) constitute the scenery of the environmental crisis. Loss of biodiversity, climate change, ice melt, plastic pollution, ocean pollution, ocean acidification and desertification are just some of the global environmental problems that make up this environmental crisis. Moreover, at the local level, the environmental crisis is taking on other aspects such as habitat loss and habitat fragmentation, extreme urban development, overconsumption of natural resources and waste disposal. In addition to the current environmental problems mentioned, new environmental problems emerge, such as climate engineering, genetic pollution and genetic drift, water stress, extended air pollution and environmental health problems, many of which are controversial topics. Increasing pressures on the environment could cause irreversible damage within the next few decades (OECD 2008). The current inaction will have an enormous impact on the environment in 2050 (OECD 2012).

Taking into account the emergency of the environmental issues, a renewed and expanded Environmental Citizenship is needed to achieve positive outcomes for the environment. Environmental Citizenship could contribute to the solution of the current environmental problems and will prevent the creation of new environmental problems. Even though there are different interpretations of Environmental Citizenship, there is a consensus of the scholars within the academy that there is a need for an effective Environmental Citizenship (Barry 2006). Such an Environmental Citizenship could develop a more sustainable society and world with the transformation of the values, beliefs, attitudes and behaviour of individuals who see themselves as part of the global environmental politic (Barry 2006).

\subsubsection{The Roots of Environmental Citizenship}

Environmental Citizenship is originally derived from the political science arena. Many different approaches for Environmental Citizenship can be found in the scientific literature. According to Melo-Escrihuela (2008), the discourse regarding Environmental Citizenship can be classified into two main categories: the personal 
duty or lifestyle approach and the participatory rights approach coming from both the liberal and republican political theories. The liberal approach gives emphasis on individual responsibility and on claiming rights to environmental goods, whilst the republican approach gives emphasis on participatory rights in decision-making, on deliberation, on civic participation and on the commitment to the common good.

There are also some other political approaches of Environmental Citizenship such as feminist, multiculturalism (pluralism) as well as cosmopolitan and neoliberal (globalism). Pluralism theories are adding to the political dialogue, the universalism and the exclusion of difference (Cao 2015). Within globalism theories, cosmopolitan Environmental Citizenship emphasises the interconnection and interdependence on a global scale beyond state boundaries (Beck 2010). Neoliberalism considers citizens as consumers; it advocates for the importance of corporations as agents of citizenship and is expressed mainly by the concepts of sustainable consumption, green consumerism and consumer-sensitive lifestyles.

These different political and philosophical approaches, which in many points seem to be contradicted, make the fostering of Environmental Citizenship by educational perspectives very complex and with unstable focus in its practical implications or educational practice.

\subsection{The Need for Conceptualisation of Environmental Citizenship}

To date, a set of similar environmental terms relevant to Environmental Citizenship have been developed and described in the educational literature, which are used each time with their own operational definition. Accordingly, concepts such as Environmental Citizenship (e.g. Dobson 2007, 2010), green citizenship (e.g. Barry 2006), ecological citizenship (e.g. Jagers and Matti 2010) and sustainability citizenship (e.g. Barry 2006) have not been clearly distinguished. Additionally, from an educational point of view, they are not clearly different in nature and they often have overlapping areas of interest among them. Therefore, the conceptualisation of the term Environmental Citizenship from an educational perspective seems to be an imperative educational necessity.

Furthermore, Environmental Citizenship is not elucidated defined in relation to other relevant concepts such as environmental education, environmental behaviour, environmental attitudes, environmental literacy, environmental knowledge, awareness, sustainability and sustainability education. The domain of Environmental Citizenship is complex. Environmental Evidence Australia's review (2012) concluded that agreement on what constitutes Environmental Citizenship and the most effective tools and approaches for implementing Environmental Citizenship are still emerging. The fragmented nature of the research findings and information related to Environmental Citizenship constrains their effective incorporation into good practices and policy frameworks in the educational context. 


\subsection{Environmental Citizenship and Education}

Education has been shown to be a fundamental tool that can adequately contribute to behavioural changes in citizens, which can eventually be translated into aspects of Environmental Citizenship (e.g. Gunningham et al. 2004; Dietz and Stern 2002). According to Huckle (2014), there is an urgent need to provide young citizens with sources of hope in troubled times, and Environmental Citizenship can provide the hope that the urgent solutions needed against modern environmental challenges can be found. Environmental Citizenship is relevant with science education (SE), environmental education (EE), Education for Sustainability (EfS) and citizenship education $(\mathrm{CE})$. Each type of education has something important to contribute to Environmental Citizenship through its specific approaches, dimensions and practices.

SE is often linked to citizenship. Many studies in science education underscore the key role of science education for promoting active and responsible citizenship, as well as the need for citizens to get involved in the decision-making processes concerning controversial socio-scientific and socio-technical issues (Roth and Désautels 2004). The inclusion of socio-scientific controversies in the science curriculum signifies a departure from the traditional science teaching into more contemporary approaches elaborating the discussion of ill-structured, open-ended topics (Kyza et al. 2018). Recently, the socio-scientific inquiry-based learning (SSIBL) framework proposed a model of concepts and practices central to inquiry, which supports teachers with integrating citizenship in science classes (Levinson 2018). The European Commission report 'Science Education for Responsible Citizenship' (Hazelkorn et al. 2015) identified the main issues involved in helping all citizens acquire the necessary knowledge of and about science to participate actively, responsibly and successfully in and with society throughout their lives. It also provides insights on how science education can help Europe achieve its goals and empower people with the skills and competences needed to deliver sustainable and competitive solutions to these challenges. Environmental problems in many cases are such complex and controversial socio-scientific issues, and students should be inducted in how to critically approach them.

In the frames of EE, many scholars argue that the ultimate goal of environmental education is to develop students' ability to act as informed and empowered citizens (e.g., Schulser et al. 2009; Chawla and Cushing 2007), and other scholars invoke environmental education as a safe way to promote Environmental Citizenship (Carlsson and Jensen 2006; Gough and Scott 2006). However, according to other scholars (e.g. Schild 2016), there still remains a lively disagreement about the aims of environmental education, which may lead to conflicting goals and outcomes. Tidball and Krasny (2010, p. 2) stated that 'some models of environmental education may even have contradictory pedagogical approaches'. Such ambiguities in targeting and priorities can act as a barrier to the effective implementation of the Education for Environmental Citizenship (EEC). In addition, many research efforts in the frames of environmental education focuses on the individualistic approach 
through which the ultimate goal is to achieve behaviouristic alterations in terms of the individual. For decades, a great deal of effort has been given to understand environmental behaviour, and several models have been proposed in the literature (e.g., Roczen et al. 2014; Corral-Verdugo 2002; Gräsel 2001). Many educational efforts have been undertaken to understand and improve the environmental behaviour of citizens. However, such models have never been elaborated in the greater framework of Environmental Citizenship. According to Chawla and Cushing (2007, pp. 9-10), 'Environmental education ... typically emphasise[s] private sphere environmentalism at the expense of preparing students for public action'. However, Environmental Citizenship has the collective action as an intrinsic dimension, apart from the personal action in a private and public sphere. This dimension of Environmental Citizenship is often not the focus of educational efforts in the context of environmental education. Many researchers (e.g. Schild 2016; Barry 2006) have advised that we need an educational model that can promote the type of strong Environmental Citizenship and to move beyond an individualistic and behaviourist approach to more deliberately integrate an Environmental Citizen's engagement in civic participation and collective action into environmental education practices.

EfS promotes three interconnected pillars of sustainability: environmental, social and economic sustainability (UN 2015). In EfS, the concept of citizenship is just 1 of the 20 key themes of sustainable development, and Environmental Citizenship is therefore not the focus in many of the approaches. In addition, there is a recorded criticism regarding under-exploiting the social dimension and issues related to social justice and socio-political engagement of active citizens (e.g. Du Pisani 2006). In addition, several approaches are trying to incorporate citizenship in EfS and are attempting to find common ground between Global Citizenship Education (GCE) and Education for Sustainable Development (ESD) (e.g. Hoskins 2016).

Finally, CE in many curricula around the world has its own contribution and is considered important in understanding how citizens could become politically empowered and active and how society is governed. Kerr (2000) points out the difference between 'passive and historical' and 'active and critical' citizenship education. A useful framework to represent the dimensions of critical CE is proposed by Johnson and Morris (2010) in which politics, social, self and praxis represent the component elements of critical citizenship education. In addition, international assessment studies regarding citizenship education such as ICCS $(2009,2016)$ gave some cover in environmental issues. However, Environmental Citizenship is not in the focus of these important studies (Schulz et al. 2016).

As can be seen from the above argumentation, Education for Environmental Citizenship has never been put into the spotlight of the literature, and it has rarely been placed at the heart of the educational efforts in the context of environmental education, science education, citizenship education and sustainability education. Therefore, there is a need for an education that will have Environmental Citizenship as its prime concern and ultimate aim. Education for Environmental Citizenship could be considered to act as this type of education. 


\subsection{The European Network for Environmental Citizenship as a Community of Practice}

The European Network for Environmental Citizenship (ENEC) - funded as a COST Action (CA16229-Horizon 2020) - brings together more than 120 experts from 37 countries with the objective to improve the understanding, the practice and the assessment of Environmental Citizenship in Europe and the participating countries. This large network bridges different fields of science and research communities so that access to more projects, experiences and perspectives can be acquired. This multi-national and multidisciplinary research context intends to bridge the gaps between human, economic, social, political and environmental sciences and to create exciting opportunities for exploiting synergies between different stakeholders (researchers, scholars, teachers, practitioners, policy officials, NGOs, etc.) regarding knowledge, expertise, research and insights of Environmental Citizenship. The ultimate objective of this national, European and international collaboration is to promote Education for Environmental Citizenship as an area of research and as a social and educational practice worldwide.

ENEC can be labelled as a community of practice (CoP): a group of people who share a concern or a passion about something they do and are learning how to do it better as they interact regularly (Wenger-Trayner and Wenger-Trayner 2015). This European network presents several of the characteristics identified by Wenger $(1998,2010)$ in a CoP:

- A shared interest - In ENEC's case, all members share a common interest in the promotion of Environmental Citizenship as a way to guarantee a more sustainable future.

- A dynamic negotiation of meaning - The network promotes the interaction between different researchers and stakeholders and the analysis of the literature in order to develop a common language and a common understanding/definition of Environmental Citizenship. This meaning-making process inside ENEC's community of practice implies both participation (discussions, meetings, scientific training schools, short-term scientific missions, conferences) and reification (documents, processes, methods, definitions, educational framework, collaborative working papers, scientific reports, proceedings, academic publications, policy and recommendation papers and an edited book on Environmental Citizenship). This way, the CoP contributes to and expands both knowledge and resources (Wenger 2010). Environmental Citizenship implementation requires a shared understanding of the concept by all stakeholders and the development of knowledge in implementing this approach.

- Shared ways of engaging in doing things together - Both the definitions (e.g. Environmental Citizenship) and the educational framework for the Education for Environmental Citizenship developed collaboratively by the network members are being used to frame a research, educational and social action agenda. 
Together, the members from different areas of knowledge are developing new research paradigms and metrics for assessing Environmental Citizenship. At the same time, ENEC fosters the growth of a specific research and social practice through the initiation and support of those entering the practice by those considered 'experts' in that practice, in a process grounded in mutual respect and the desire to contribute to the practice (Lave and Wenger 1991). The CoP shares a common interest and passion and creates its own knowledge and resources.

- A rapid flow of information and innovation - The development of an interactive platform for communication and exchange of information regarding research and evidence-based interventions targeting Environmental Citizenship, combined with the use of digital collaboration and communication tools and the frequent meetings (working meetings, scientific training schools and short-term scientific missions), assures the constant and fast contact between the network's members. The interactive platform intends to overcome what is considered as one of the major threads to the implementation of ENEC's approach: the availability of resources. In spite of existing several learning materials and programmes on Education for Environmental Citizenship proposed by different organisations, these resources are dispersed through a multitude of places. Therefore, the interactive platform 'GAIA Repository Database' concentrates relevant information in one specific and dedicated space, aiming to become a major forum of discussion and dissemination regarding Education for Environmental Citizenship.

- A shared knowledge of each member competences - The members' different competences are being mobilised towards the network's goals, providing a richness of knowledge and perspectives. The promotion of Environmental Citizenship requires an interdisciplinary, collaborative and systemic approach difficult to materialise in schools strongly organised or divided around subjects. ENEC is providing the common spaces and times needed to develop synergies among different knowledge, perspectives and specific cultures.

- The development of an identity - all the interactions and collaborative work inside the network are allowing the development of an identity through the accumulation of experiences, stories, classroom materials and ways of addressing recurring problems, knowledge and competences connected with fostering Environmental Citizenship.

- A shared discourse reflecting a certain world view about the importance of citizens' pro-environmental behaviour change - through Environmental Citizenship - in order to aim for a more sustainable world.

ENEC is being fostered as a CoP through three key elements highlighted by the literature (Sherer et al. 2003; Wenger et al. 2002): (1) domain, the shared repertoire of knowledge and competences; (2) community, the interaction and the collective learning through joint activities and discussions; and (3) practice, the shared repertoire of resources developed by the community. 


\subsection{ENEC Definitions: EC, EEC and ECn}

The European Network for Environmental Citizenship (ENEC) has set the following definitions for 'Environmental Citizenship' (EC), 'Education for Environmental Citizenship' (EEC) and 'Environmental Citizen' (ECn). These definitions were agreed after discussions from more than 120 researchers and scholars from 37 countries. The ENEC's definitions provide a concrete base on the conceptualisation of the Environmental Citizenship for twenty-first-century education.

'Environmental Citizenship' is defined as the responsible pro-environmental behaviour of citizens who act and participate in society as agents of change in the private and public sphere on a local, national and global scale, through individual and collective actions in the direction of solving contemporary environmental problems, preventing the creation of new environmental problems, achieving sustainability and developing a healthy relationship with nature. 'Environmental Citizenship' includes the practise of environmental rights and duties, as well as the identification of the underlying structural causes of environmental degradation and environmental problems and the development of the willingness and the competences for critical and active engagement and civic participation to address those structural causes and to act individually and collectively within democratic means, taking into account inter- and intra-generational justice (ENEC 2018a).

'Education for Environmental Citizenship' is defined as the type of education that cultivates a coherent and adequate body of knowledge as well as the necessary skills, values, attitudes and competences that an Environmental Citizen should be equipped with in order to be able to act and participate in society as an agent of change in the private and public sphere on a local, national and global scale, through individual and collective actions in the direction of solving contemporary environmental problems, preventing the creation of new environmental problems, achieving sustainability as well as developing a healthy relationship with nature. 'Education for Environmental Citizenship' is important to empower citizens to practise their environmental rights and duties, as well as to identify the underlying structural causes of environmental degradation and environmental problems, develop the willingness and the competences for critical and active engagement and civic participation to address those structural causes and act individually and collectively within democratic means, taking into account the inter- and intra-generational justice (ENEC 2018b).

'Environmental Citizen' is defined as the citizen who has a coherent and adequate body of knowledge as well as the necessary skills, values, attitudes and competences in order to be able to act and participate in society as an agent of change in the private and public sphere on a local, national and global scale, through individual and collective actions in the direction of solving contemporary environmental problems, preventing the creation of new environmental problems, achieving sustainability as well as developing a healthy relationship with nature. An 'Environmental Citizen' is a citizen who practises his/her environmental rights and duties, is able to identify the underlying structural causes of environmental degradation and 
environmental problems and has the willingness and the competences for critical and active engagement and civic participation to address those structural causes and to act individually and collectively within democratic means, taking into account inter- and intra-generational justice (ENEC 2018c).

Based on the above definitions, when we refer to Environmental Citizenship in the following chapters, we refer to an umbrella concept which covers all the different interpretations and views of the relation between environment and citizenship (e.g. green citizenship, sustainability citizenship, ecological citizenship, etc.) rather than just the liberal interpretation of Environmental Citizenship. We consider it important to have only one umbrella term (Environmental Citizenship) from the educational point of view. In addition, it is important to clarify that terms 'citizen' and 'citizenship' are not marginalizing any individuals who are not legally deemed to be citizens of a specific state or country.

\subsection{The Structure of the Book}

This book is organised in four complementary parts. Part I refers to the political, economic and social dimensions of Environmental Citizenship. Part II examines Environmental Citizenship as a psychological concept. In Part III, Environmental Citizenship is examined in the context of environmental education and education for sustainability. Finally, in Part IV Environmental Citizenship is discussed in different educational levels: primary and secondary formal and non-formal settings.

Part I begins with Chap. 2 about the "Political Dimensions of Environmental Citizenship". In this text, Ralph Levinson and his co-authors analyse the relation between conceptions of Environmental Citizenship and different models of sustainability. Some metaphysical and ontological questions about the relationship between Mind and Nature raised by divergent ideologies are discussed in this chapter, together with several fundamental implications for education and citizenship.

Chapter 3 discusses the relationship between economics and the environment, with a special focus on the environmental consequences of the widely applied principles of mainstream economics. Vladislav Kaputa and his colleagues argue for an interdisciplinary approach as a possible way to overcome the political and social barriers that prevent the transformation of economic systems. Environmental Citizenship is presented as a major element in shaping individual attitudes and values with a positive impact on consumer behaviour and, consequently, in the environment.

In Chap. 4, Ivan Sulc and his co-authors examine the role of Environmental Citizenship in selected aspects of human activities - urban development, transport systems, tourism and cultural heritage. The chapter analyses the relation of Environmental Citizenship, urban development and cultural landscapes. Sustainable transport is suggested as a way of reducing the transport disadvantage of marginalised social groups. Cultural heritage is identified as a new fourth pillar of sustainable development (along with environment, economy and society), and its role in 
Environmental Citizenship is investigated. Finally, sustainable tourism is reviewed using new approaches in tourism that adopted elements of Environmental Citizenship as a reaction to unsustainable mass tourism.

In Part II, Environmental Citizenship is examined as a psychological concept. This part begins with Chap. 5 centred on the relationships between knowledge and Environmental Citizenship. In this text, Marija Smederevac-Lalic and colleagues present knowledge as an essential element in influencing pro-environmental behaviour and, consequently, in developing Environmental Citizenship. They explore what knowledge is necessary for an Environmental Citizen to cultivate coherent and adequate skills, values, attitudes and competences. Finally, they suggest a process of co-production of new knowledge between experts and key citizens as central to the idea of a participatory approach towards developing Environmental Citizenship.

Audra Balunde and her co-authors of Chap. 6 discuss how beliefs and values relate to Environmental Citizenship and how these aspects can be targeted in order to educate Environmental Citizens worldwide. In their opinion, understanding how values and beliefs relate to Environmental Citizenship would allow for evidencebased ways of promoting Environmental Citizenship in schools and communities.

In Chap. 7, Nicole Bauer and colleagues analyse how attitudes and Environmental Citizenship are related to each other. The chapter focuses mainly on the individual level of describing the factors that influence Environmental Citizenship. Special attention is given to the process how attitudes toward Environmental Citizenship can develop.

The notion of Environmental Citizenship embodies behaviour - an actively involved citizen who is practising his/her environmental rights and obligations in the private and public spheres. In Part III, Chap. 8 Daphne Goldman and her coauthors examine the relationship between Environmental Citizenship and responsible environmental behaviour. They consider that the social and psychological study of behaviour has much to inform the study of environmental behaviour and how to reach the goal of sustainable socioecological transformation. The chapter presents selected models on the factors that influence behavioural decisions as well as various theories that inform these models. The chapter concludes with some suggestions for Education for Environmental Citizenship deriving from the various models.

Youth democratic activism develops young people's critical scientific literacy, which is an important element of Environmental Citizenship. In Chap. 9, Pedro Reis discusses the concept of activism and the importance of activism initiatives in the development of citizens' willingness and competences for critical, active and democratic engagement in preventing and solving environmental problems. Several possible pathways for young people to get involved in activism are presented, and a combination of youth activism with citizen science is also discussed.

Environmental Citizenship is examined within the frames of the EfS. The similarities and differences between Education for Environmental Citizenship and EfS are discussed by Gemma Parra and her co-authors in Chap. 10. Specific educational approaches and methodologies are suggested that may be effective in promoting essential qualities in Environmental Citizens. The proposal of specific Education for 
Environmental Citizenship competences and how education and teachers can promote these competences are also important points in this chapter.

Part IV starts with Chap. 11 where Environmental Citizenship is examined in primary formal education. Jan Činčera and his co-authors start from the point that primary formal education can provide opportunities to achieve Environmental Citizenship goals. They present how the specifics of age and formal settings could be approached and which educational strategies could be used, recommended or avoided based on the existing research. This chapter also provides an overview of the most important educational aims regarding the development of Environmental Citizenship in primary formal education, namely, environmental sensitivity, a sense of justice, a basic understanding of ecological systems, skills for basic investigation of ecological and social phenomena and action skills relating to active participation in community issues.

The aim of Chap. 12 is to explore how non-formal education can take place for young children (primary education) as a space to experiment with and to learn the competences needed as Environmental Citizens. Boeve-de Pauw explores the potential of non-formal education to facilitate the development of children's environmental identity and their identity as agents of change. An overview of significant life experiences that can contribute to this development is presented. The chapter identifies key aspects in implementing the concept of Environmental Citizenship, which should focus on the experiences encountered by children in their 'reality' and should be based on participatory principle and negotiated in a very flexible framework.

In Chap. 13, Niklas Gericke and his colleagues focus on the demands and challenges that need to be overcome and are related to context differences as well as to formal education requirements in order to enact Environmental Citizenship teaching approaches in secondary education. In secondary education, students are taught by several subject specialists from different disciplines. To enact Education for Environmental Citizenship, these different teachers need to collaborate. Moreover, secondary schooling might have different aims compared to other school forms, and it is often regulated with specific subject syllabi. How Education for Environmental Citizenship can be enacted considering these challenges is also discussed in this chapter.

Education for Environmental Citizenship in non-formal frameworks for secondary level youth is another important dimension covered by this book. In Chap. 14, Paraskeva-Hadjichambi and her co-authors deduce that non-formal settings for secondary education level could contribute to Education for Environmental Citizenship by providing the opportunities and conditions that enable young people to be empowered and motivated to act and participate in society as agents of change in the direction of solving contemporary environmental problems, preventing the creation of new environmental problems, achieving sustainability and restoring human relationships with nature. They present how different pedagogies including place-based education, civic ecology education, ecojustice pedagogy, action competence and socio-scientific inquiry-based learning can all contribute to achieve environmental and social change. They conclude the chapter by emphasising the need for a complete pedagogical framework fostering Education for Environmental Citizenship. 
In the final chapter of the book, Chap. 15, Hadjichambis and ParaskevaHadjichambi summarise a specific model (EEC model) of the Education for Environmental Citizenship that needs to be fostered, recording the outputs, dimensions, scales and the spheres of Environmental Citizenship. In addition, a specific pedagogical approach is proposed that can effectively promote EEC model. The chapter draws the pedagogical landscape of Education for Environmental Citizenship and describes the stages and the steps of this innovative, integrated and holistic pedagogical approach. This chapter discusses the need for curriculum and learning materials fostering Education for Environmental Citizenship and argues for the vital role of schools and educational institutions and the crucial role of teachers and teachers' professional development for the adequate establishment of Education for Environmental Citizenship.

Acknowledgement This chapter is based on work from Cost Action ENEC - European Network for Environmental Citizenship (CA16229) - supported by COST (European Cooperation in Science and Technology).

\section{References}

Barry, J. (2006). Resistance is fertile: From environmental to sustainability citizenship. In A. Dobson \& D. Bell (Eds.), Environmental citizenship (pp. 21-48). Cambridge: MIT Press.

Beck, U. (2010). Remapping social inequalities in an age of climate change: For a cosmopolitan renewal of sociology. Global Networks, 10(2), 165-181.

Cao, B. (2015). Environment and citizenship. London: Routledge.

Carlsson, M., \& Jensen, B. B. (2006). Encouraging environmental citizenship: The roles and challenges for schools. In A. Dobson \& D. Bell (Eds.), Environmental citizenship (pp. 237-261). Cambridge, MA: The MIT Press.

Chawla, L., \& Cushing, D. F. (2007). Education for strategic environmental behaviour. Environmental Education Research, 13(4), 437-452.

Corral-Verdugo, V. (2002). A structural model of pro environmental competency. Environment and Behavior, 34, 531-549.

Dietz, T., \& Stern, P. C. (2002). New tools for environmental protection: Education, information, and voluntary measures. Washington, DC: National Academy Press.

Dobson, A. (2007). Environmental citizenship: Towards sustainable development. Sustainable Development, 15(5), 276-285.

Dobson, A. (2010). Environmental citizenship and pro-environmental behavior: Rapid research and evidence review. London: Sustainable Development Research Network.

Du Pisani, J. A. (2006). Sustainable development - Historical roots of the concept. Journal of Environmental Sciences, 3, 83-96.

Environmental Evidence Australia. (2012). A review of best practice in environmental citizenship models. Victoria: Environmental Evidence Australia.

European Network for Environmental Citizenship - ENEC. (2018a). Defining "Environmental Citizenship". Retrieved from http://enec-cost.eu/our-approach/enec-environmental-citizenship/

European Network for Environmental Citizenship - ENEC. (2018b). Defining "Education for Environmental Citizenship". Retrieved from http://enec-cost.eu/our-approach/ education-for-environmental-citizenship/

European Network for Environmental Citizenship - ENEC. (2018c). Defining "Environmental Citizen". Retrieved from http://enec-cost.eu/environmental-citizen/ 
Gough, S., \& Scott, W. (2006). Promoting environmental citizenship through learning: Toward a theory of change. In A. Dobson \& D. Bell (Eds.), Environmental citizenship (pp. 263-285). Cambridge, MA: The MIT Press.

Gräsel, C. (2001). Ökologische Kompetenz: Analyse und Förderung [Ecological competence: Analysis and promotion]. (Unpublished habilitation thesis). Munich: Ludwig Maximilian University.

Gunningham, N., Kagan, R. A., \& Thornton, D. (2004). Social license and environmental protection: Why businesses go beyond compliance. Law \& Social Inquiry, 29(2), 307-341.

Hazelkorn, E., Ryan, C., Beernaert, Y., Constantinou, C. P., Deca, L., Grangeat, M., Karikorpi, M., Lazoudis, A., Casulleras, R. P., \& Welzel-Breuer, M. (2015). Science education for responsible citizenship. Report to the European Commission of the Expert Group on Science Education. Luxembourg: Publications Office of the European Union.

Hoskins, V. (2016). Towards the development of an international module for assessing learning in Global Citizenship Education (GCE) and Education for Sustainable Development (ESD): A critical review of current measurement strategies. Background paper prepared for the 2016 Global Education Monitoring Report Education for people and planet: Creating sustainable futures for all. UNESCO.

Huckle, J. (2014). Education for sustainability citizenship in Europe. Open Citizenship, 5(1), $32-47$.

Jagers, S. C., \& Matti, S. (2010). Ecological citizens: Identifying values and beliefs that support individual environmental responsibility among Swedes. Sustainability, 2, 1055-1079.

Johnson, L., \& Morris, P. (2010). Towards a framework for critical citizenship education. The Curriculum Journal, 21(1), 77-96.

Kerr, D. (2000, September). The making of citizenship in the National Curriculum (England): Issues and challenges. In Paper presented at the European Conference on Educational Research (Vol. 20, 23).

Kyza, E. A., Georgiou, Y., Hadjichambis, A. C., \& Agesilaou, A. (2018). Antibiotics in livestock: Introducing in-service teachers to the nature of contemporary socio-scientific controversies. The School Science Review, 100(371), 53-58.

Lave, J., \& Wenger, E. (1991). Situated learning: Legitimate peripheral participation. New York: Cambridge University Press.

Levinson, R. (2018). Introducing socio-scientific inquiry-based learning (SSIBL). School Science Review, 100(371), 31-35.

Melo-Escrihuela, C. (2008). Promoting ecological citizenship: Rights, duties and political agency. ACME: An International E-Journal for Critical Geographies, 7(2), 113-134.

Ockwell, D., Whitmarsh, L., \& O'Neill, S. (2009). Reorienting climate change communication for effective mitigation: Forcing people to be green or fostering grass-roots engagement? Science Communication, 30(3), 305-327.

OECD. (2012). OECD Environmental Outlook to 2050: The consequences of inaction. Paris: OECD Publishing. https://doi.org/10.1787/9789264122246-en.

OECD Publishing. (2008). OECD environmental outlook to 2030. Paris: Organization for Economic Co-operation and Development.

Roczen, N., Kaiser, F. G., Bogner, F. X., \& Wilson, M. (2014). A competence model for environmental education. Environment and Behavior, 46(8), 972-992.

Roth, W. M., \& Désautels, J. (2004). Educating for citizenship: Reappraising the role of science education. Canadian Journal of Math, Science \& Technology Education, 4(2), 149-168.

Schild, R. (2016). Environmental citizenship: What can political theory contribute to environmental education practice? The Journal of Environmental Education, 47(1), 19-34.

Schulz, W., Ainley, J., Fraillon, J., Losito, B., \& Agrusti, G. (2016). IEA international civic and citizenship education study 2016 assessment framework. Cham: Springer.

Schusler, T. M., Krasny, M. E., Peters, S. J., \& Decker, D. J. (2009). Developing citizens and communities through youth environmental action. Environmental Education Research, 15(1), $111-127$. 
Sherer, P. D., Shea, T. P., \& Kristensen, E. (2003). Online communities of practice: A catalyst for faculty development. Innovative Higher Education, 27(3), 183.

Stern, P. C. (2011). Contributions of psychology to limiting climate change. American Psychologist, 66(4), 303.

Tidball, K. G., \& Krasny, M. E. (2010). Urban environmental education from a social-ecological perspective: Conceptual framework for civic ecology education. Cities and the Environment (CATE), 3(1), 11.

UN. (2015). Transforming our world: the 2030 Agenda for Sustainable Development. Resolution 70/1 adopted by the General Assembly on 25 September 2015. Available at: http://www.un.org/ en/ga/70/resolutions.shtml. Accessed Jan 2019.

Wenger, E. (1998). Communities of practice: Learning, meaning, and identity. New York: Cambridge University Press.

Wenger, E. (2010). Communities of practice and social learning systems: The career of a concept. In C. Blackmore (Ed.), Social learning systems and communities of practice (pp. 179-198). Berlin: Springer/Open University.

Wenger, E., McDermott, R. A., \& Snyder, W. (2002). Cultivating communities of practice: A guide to managing knowledge. Boston: Harvard Business School Press.

Wenger-Trayner, E., \& Wenger-Trayner, B. (2015). Communities of practice: A brief introduction. http://wenger-trayner.com/introduction-to-communities-of-practice/. Accessed 20 Aug 2018.

Open Access This chapter is licensed under the terms of the Creative Commons Attribution 4.0 International License (http://creativecommons.org/licenses/by/4.0/), which permits use, sharing, adaptation, distribution and reproduction in any medium or format, as long as you give appropriate credit to the original author(s) and the source, provide a link to the Creative Commons license and indicate if changes were made.

The images or other third party material in this chapter are included in the chapter's Creative Commons license, unless indicated otherwise in a credit line to the material. If material is not included in the chapter's Creative Commons license and your intended use is not permitted by statutory regulation or exceeds the permitted use, you will need to obtain permission directly from the copyright holder.

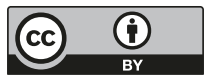

